\title{
Differential Response of Mungbean (Vigna radiata L.) Varieties to Changes in Environmental Conditions
}

\author{
Renu Singh ${ }^{1 *}$, Adriaan W. Van Heusden ${ }^{2}$, Suman Bala $^{1}$ and Richard G.F. Visser ${ }^{2}$ \\ ${ }^{1}$ Centre for Plant Biotechnology, Hisar, Haryana - 125004, India \\ ${ }^{2}$ Plant Research International (PRI), Wageningen University, The Netherlands \\ *Corresponding author
}

\begin{tabular}{l} 
K e y w o r d s \\
$\begin{array}{l}\text { Environmental index, } \\
\text { Genotype x Environment, } \\
\text { Micronutrients, Stability }\end{array}$ \\
\hline Article Info \\
\hline $\begin{array}{l}\text { Accepted: } \\
\text { 20 February } 2018 \\
\text { Available Online: } \\
10 \text { March } 2018\end{array}$ \\
\hline
\end{tabular}

A B S T R A C T
One of the benefits of mungbeans is its nutritional properties. Of the seven essential micronutrients, especially iron and zinc play a vital role in human and animal health. Breeding for varieties with a potential high concentration of micronutrients should be complemented with studies of environmental effects on the accumulation of micronutrients in seeds. Our major emphasis was to see the effect of iron and zinc supplementation on seed micronutrient content and other agronomic traits. Therefore, to study different compositions of the soil, six artificial conditions with different levels of micronutrients were created. Soil supplemented with $\mathrm{ZnSO}_{4}$ or with $\mathrm{ZnSO}_{4}$ and $0.5 \% \mathrm{FeSO}_{4}$ was beneficial for agronomic traits but not favorable for iron and zinc content of seeds. The main effects and interactions were statistically significant different.

\section{Introduction}

Mungbean is a widely grown food grain legume in the developing world. Mungbeans are locally grown and available for the local people. In India, there is always production in one state or the other. Dry beans, including mungbean (19.7 million tonnes (mt), field pea (10.4 mt), chickpea (9.7 mt), cowpea (5.7 mt), lentil $(3.6 \mathrm{mt})$ and pigeon pea $(3.5 \mathrm{mt})$, are important crops (FAO, 2010). The majority of population in India is vegetarian therefore dry beans and especially mungbean is a major replacement of animal proteins and micronutrients. Iron and zinc play a very important and vital role in the health and development of animals, humans and plants, therefore increasing their content in seed will may prove helpful in combatting micronutrient deficiency in a vegetarian society.

Major constraints in breeding pulses such as mungbean are the high genotype $x$ environment $(\mathrm{GxE})$ interactions and the low genetic diversity in the primary gene pool (Jitendra et al., 2011). Several other studies (Tiwari et al., 2000; Mehla et al., 2000) 
showed large GxE interactions which make it necessary to test new varieties over a large number of environments. Wu and O'Malley (1998) describe two types of environmental variation: (1) micro environmental effects which can't easily be identified or predicted (e.g., year-to-year variation in rainfall, drought conditions, extent of insect damage) and (2) macro environmental variances which are known (e.g., soil type, management practices, controlled temperatures etc.). According to these investigators, the $\mathrm{GxE}$ interaction can only be estimated for the macro environmental effects. Breeding programs should aim at genotypes that perform well under as many conditions as possible. Therefore testing new varieties under varying local growing conditions is of utmost importance. Besides it is important to know the available germplasm and to know the relationship between different accessions; landraces and cultivars. Therefore in order to test the performance of the selected mungbean cultivars to the different soil types, a total of six artificial soil environments were created. These artificially created environments made it possibility to study the stability of mungbean cultivars for micronutrient content (iron and zinc) and important agronomic traits like yield.

\section{Materials and Methods}

\section{Plant material}

The experiments were conducted with thirty elite genotypes growing in six different artificial soil types. The genotypes were selected on the basis of contrasts in micronutrient content and agronomic performance (Singh et al., 2013).

\section{Field trials and experimental design}

Six different field environments were created at the pulses station, CCS HAU, Hisar, located at latitude of $29^{\circ} 10^{\prime} \mathrm{N}$, longitude of $75^{\circ} 46^{\prime} \mathrm{E}$ and altitude $215.2 \mathrm{~m}$ above sea level. The experiment was conducted in the kharif (July to September) 2009, in a Random Block Design with spacing of $40 \mathrm{~cm}$ between rows and $15 \mathrm{~cm}$ between plants within the row. The different environments were created by adding different doses of micronutrients and fertilizer to the soil (Table 1). The recommended dose of fertilizers (RDF) was added in all soils. Single Super Phosphate (SSP) and zinc were added according to the recommendations of an experienced agronomist. Chelated iron can be applied directly as a foliar spray (Fig. 1) to enhance uptake.

An optimal supply of nitrogen $(20 \mathrm{~kg} /$ hectare $)$ ensures an optimal uptake of potassium as well as phosphorus, iron, zinc etc. (RanadeMalvi 2011). The mean maximum/minimum temperature during the period of the study was $36.1 / 24.8^{\circ} \mathrm{C}$, while the mean relative humidity was $81.7 \%$ (morning) $/ 51.1 \%$ (evening). The soil of the present experimental field is from the Indo-Gangetic alluvium and is in texture loamy sand.

Before adding any fertilizer to the experimental fields, the physical-chemical characteristics of the soil were measured (Table 2). Soil samples were taken from 6 to 8 inches under the surface (the aerobic zone where most root growth and nutrient exchange happens). In total five samples were taken (from four corners and one from the center of the field). Each sample was approximately equal in size and placed in a clean plastic bucket and mixed thoroughly and sends to the soil testing laboratory of the department of soil, CCS HAU, Hisar.

After foliar spray of iron (Fig. 1) and soil supplementation with $\mathrm{ZnSO}_{4}$ and $\mathrm{RDF}$, in the middle of the growth season samples of soil were again analyzed. To measure mungbean yield some yield related traits were measured. Five random plants were tested per row and 
plant height $(\mathrm{cm})$, number of pods/plant, number of branches per plant, seed yield/plant (g) were measured. Along with these parameters, the iron and zinc content of the seed samples grown under different environments were analyzed.

\section{Stability analysis}

Statistical analysis was carried out with software OPStat (http://www.hau.ernet.in/ link/spas.htm). The data for each trait were subjected to analysis of variance using the general linear model for RBD design. The appropriate ' $F$ ' values were obtained for testing the significance of genotypes against error mean square in accordance with the following model: $Y i j=m+a_{i}+b_{j}+e_{i j}$ where, $m$ is general mean, $a_{i}$ is $i^{\text {th }}$ treatment level, $b_{j}$ is $j^{\text {th }}$ replication level and $e_{i j}$ is random error associated with treatment for $\mathrm{j}^{\text {th }}$ block.

The mean values for different traits of all thirty genotypes in six environments as well as pooled over environments were used for analysis of variance for phenotypic stability.

\section{Results and Discussion}

The data in Table 2 show, that the loamy sandy soil of the experimental field is alkaline, low in available nitrogen (appendix I), medium in Fe, phosphorus, potassium, sulphur and $\mathrm{Zn}$.

\section{Selecting the right percentage of iron for foliar application}

In order to select the appropriate iron percentage a small experiment was conducted. Three concentrations i.e. $0.5 \%, 0.75 \%$ and $1.0 \%$ of $\mathrm{FeSO}_{4}$ solution were tested. No visible signs were present with $0.5 \%$ but with $0.75 \%$ and $1.0 \%$ leaves were damaged (Fig. 2).
Effect of changes in the environment on performance genotypes

\section{Analysis of variance}

An analysis of variance (ANOVA), based on group variances and sample sizes tells, whether there is a statistically significant difference between group means (averages).

A simple randomized block design analysis was carried out for different traits and six soil environments. ANOVA for different traits in all the environments was carried out to test the significance of phenotypic differences i.e. to see the presence of significant variation for a trait in different environments. In order to test the significance, $\mathrm{F}$ values were calculated by using the factor mean sum square against error mean square and further significance was tested against the tabulated values.

It is evident from Table 3 that mean squares due to genotypes were significant in all the environments for all traits except for plant height which was non-significant in $\mathrm{E}_{2}$. The critical difference values showed that enough sufficient genetic variation was present for most of the traits.

\section{Estimation of environmental index (Ij) - grading of environments}

The performance of a particular variety is the result of its genetic constitution and the environment in which it grows. In order to see which environment causes poor, fair or optimal growing conditions an environmental index can be estimated. The environmental index shows the suitability of an environment for the expression of a certain trait. The estimates of environmental index for all the six environments and traits are expressed as deviation from the mean of all the genotypes at a given location from the overall mean (Table 4). 
Fig.1 Mungbean plant stage at which micronutrients were added
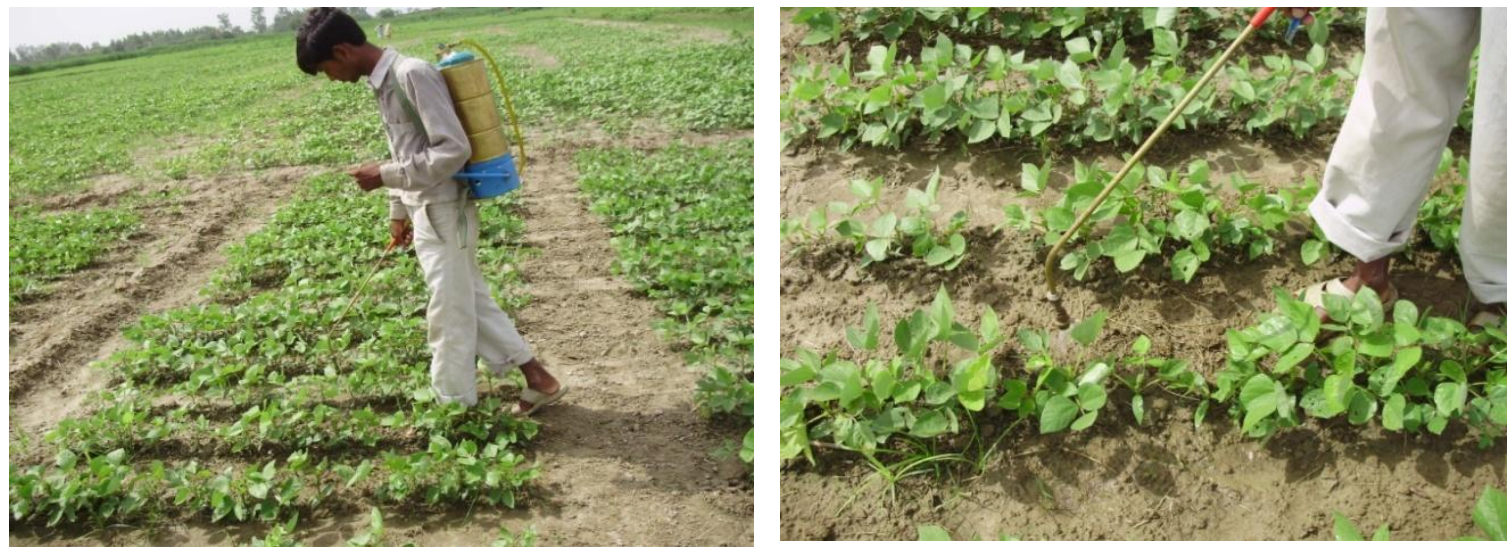

Fig.2 Effect of foliar application of iron $\left(\mathrm{FeSO}_{4}\right)$ on mungbean leaves
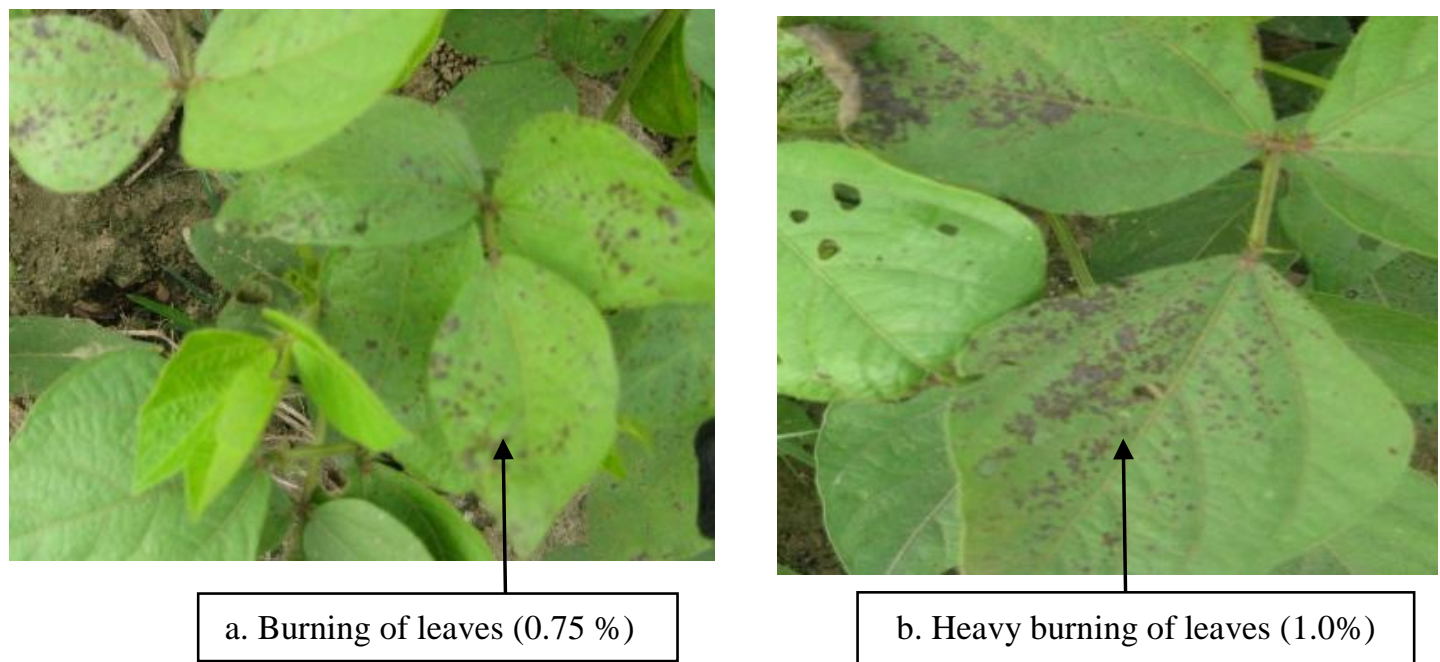

b. Heavy burning of leaves (1.0\%)

Table.1 Details of artificial field environments

\begin{tabular}{|c|c|c|l|}
\hline Environment & Genotypes & No. of replications & \multicolumn{1}{|c|}{ Fertilizer doses } \\
\hline E1 & 30 & 3 & $\mathrm{RDF}$ \\
\hline E2 & 30 & 3 & $\mathrm{RDF}+0.5 \% \mathrm{FeSO}_{4}$ \\
\hline E3 & 30 & 3 & $\mathrm{RDF}+\mathrm{SSP}$ \\
\hline E4 & 30 & 3 & $\mathrm{RDF}+\mathrm{SSP}+0.5 \% \mathrm{FeSO}_{4}$ \\
\hline E5 & 30 & 3 & $\mathrm{RDF}+\mathrm{SSP}+\mathrm{ZnSO} 4$ \\
\hline E6 & 30 & 3 & $\mathrm{RDF}+\mathrm{SSP}+\mathrm{ZnSO}_{4}+0.5 \%$ \\
\hline
\end{tabular}

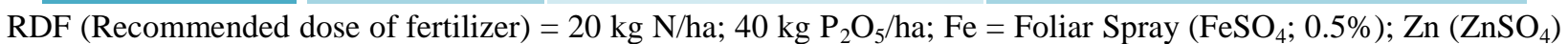
$=$ direct to soil $(25 \mathrm{~kg} / \mathrm{ha})$; $\mathrm{SSP}\left(\right.$ Single Super Phosphate, $\left.\mathrm{Ca}\left(\mathrm{H}_{2} \mathrm{OP}_{4}\right) 2 . \mathrm{H}_{2} \mathrm{O}\right)=$ contains $16 \%$ water soluble $\mathrm{P}_{2} \mathrm{O}_{5}$, $12 \%$ sulphur \& $21 \%$ calcium. 
Int.J.Curr.Microbiol.App.Sci (2018) 7(3): 2343-2350

Table.2 Analysis of soil physicochemical characteristics

\begin{tabular}{|c|c|c|c|c|c|}
\hline \multicolumn{6}{|c|}{ Soil characteristics } \\
\hline \multicolumn{6}{|c|}{ Macronutrients (ppm) } \\
\hline $\mathrm{pH}$ & Texture & Nitrogen $(\mathbf{N})$ & Phosphorus (P) & \multicolumn{2}{|c|}{ Potassium (K) } \\
\hline 7.80 & loamy sandy & 72 & 1.4 & \multicolumn{2}{|c|}{12.4} \\
\hline \multicolumn{6}{|c|}{ Micronutrient (ppm) primary (Fe, Zn, Mn \& $\mathrm{Cu}$ ) and secondary (S) } \\
\hline & Fe & Zn & Mn & $\mathbf{C u}$ & $\mathbf{S}$ \\
\hline $\begin{array}{l}\text { Before supple- } \\
\text { mentation and } \\
\text { sowing }\end{array}$ & 24.0 & 1.10 & 8.32 & 1.18 & 16.25 \\
\hline $\begin{array}{l}\text { After supple- } \\
\text { mentation (mid } \\
\text { stage) }\end{array}$ & 8.40 & 0.86 & 2.87 & 0.58 & 600.0 \\
\hline After harvest & 5.05 & 2.02 & 1.39 & 0.44 & 520.0 \\
\hline
\end{tabular}

Table.3 Analysis of variance for six traits in mungbean under six different environmental conditions

\begin{tabular}{|c|c|c|c|c|c|c|c|c|}
\hline Source of variation & d.f & Environments & $\mathbf{P H}^{3 *}$ & NPP & NBP & SYP & $\mathrm{Fe}$ & $\mathrm{Zn}$ \\
\hline \multirow[t]{6}{*}{ Factor Block } & \multirow[t]{6}{*}{2} & E 1 & $30.56 * *$ & 0.01 & 11.85 & 4.01 & 0.89 & $9.68 * *$ \\
\hline & & E 2 & 5.28 & 0.14 & 0.36 & 1.34 & $38.13 * *$ & $3.84 * *$ \\
\hline & & E 3 & 1.06 & 0.16 & 7.79 & 1.23 & $34.70 * *$ & $5.22 * *$ \\
\hline & & E 4 & $23.15^{* *}$ & 0.03 & 7.04 & 0.20 & $10.52 * *$ & 0.23 \\
\hline & & E 5 & $16.06^{*}$ & 0.01 & 3.68 & 1.33 & $32.99 * *$ & $0.23 * *$ \\
\hline & & E 6 & 0.30 & 0.02 & 6.80 & $10.96^{*}$ & $11.18 * *$ & $4.87 * *$ \\
\hline \multirow[t]{6}{*}{ Factor Genotype } & \multirow[t]{6}{*}{29} & E 1 & $268.68 * *$ & $0.75 * *$ & $148.35^{* *}$ & $85.01 * *$ & $3.18 * *$ & $0.71 * *$ \\
\hline & & E 2 & 290.88 & $0.58 * *$ & $133.79 * *$ & $75.89 * *$ & $31.01 * *$ & $12.16 * *$ \\
\hline & & E 3 & $235.34 * *$ & $0.73 * *$ & $106.09 * *$ & $113.15^{* *}$ & $30.54 * *$ & $2.17 * *$ \\
\hline & & E 4 & $239.55^{* *}$ & $1.02 * *$ & $52.06 * *$ & $76.12 * *$ & $13.79 * *$ & $1.35^{* *}$ \\
\hline & & E 5 & $241.57 * *$ & $0.61 * *$ & $44.42 * *$ & $60.53 * *$ & $92.62 * *$ & $1.35^{* *}$ \\
\hline & & E 6 & $287.59 * *$ & $1.29 * *$ & $204.62 * *$ & $126.36^{* *}$ & $35.43 * *$ & $36.91 * *$ \\
\hline \multirow[t]{6}{*}{ Error } & \multirow[t]{6}{*}{58} & E 1 & 4.07 & 0.08 & 10.62 & 2.65 & 1.09 & 0.33 \\
\hline & & E 2 & 2.81 & 0.07 & 4.86 & 1.31 & 1.17 & 0.07 \\
\hline & & E 3 & 4.38 & 0.09 & 3.47 & 1.19 & 1.25 & 0.12 \\
\hline & & E 4 & 3.63 & 0.09 & 6.56 & 0.88 & 10.17 & 0.04 \\
\hline & & E 5 & 5.46 & 0.06 & 2.69 & 1.28 & 1.16 & 0.04 \\
\hline & & E 6 & 1.09 & 0.035 & 2.89 & 1.67 & 0.57 & 0.17 \\
\hline \multirow[t]{6}{*}{$\mathrm{CD}^{+}(5 \%)$} & & E 1 & 4.69 & 0.67 & 7.59 & 3.79 & 2.45 & 1.34 \\
\hline & & E 2 & 3.90 & 0.61 & 5.13 & 2.66 & 2.51 & 0.60 \\
\hline & & E 3 & 4.87 & 0.71 & 4.33 & 2.53 & 2.61 & 0.82 \\
\hline & & E 4 & 4.43 & 0.69 & 5.96 & 2.19 & 7.42 & 0.39 \\
\hline & & E 5 & 5.41 & 0.58 & 3.79 & 2.63 & 2.51 & 0.39 \\
\hline & & E 6 & 2.43 & 0.44 & 3.96 & 3.01 & 1.76 & 0.95 \\
\hline
\end{tabular}

**Significant at $\mathrm{P}=0.01$; Significant at $\mathrm{P}=0.05$ seeds; ${ }^{+} \mathrm{CD}=$ critical difference which depends on the MSE \& the sample sizes; ${ }^{* * *}$ PH: Plant Height (cm), NBP: number of braches/plant, NPP: number of pods/plant, SYP: seed yield, $\mathrm{Fe}$; iron seed content, Zn: zinc seed content 
Table.4 Environmental index of six traits of mungbean

\begin{tabular}{|c|l|c|c|c|c|c|c|}
\hline $\begin{array}{c}\text { Environmen } \\
\mathbf{t}\end{array}$ & \multicolumn{1}{|c|}{ Fertilizer doses } & PH & NBP & NPP & SYP & Fe & Zn \\
\hline $\mathbf{E 1}$ & RDF & 10.02 & 0.15 & 5.93 & 1.89 & -1.23 & -0.34 \\
\hline $\mathbf{E 2}$ & RDF + 0.5\% $\mathrm{FeSO}_{4}$ & 2.62 & 0.08 & 2.47 & 0.63 & -0.47 & 0.87 \\
\hline $\mathbf{E 3}$ & $\mathrm{RDF}+\mathrm{SSP}$ & -1.28 & 0.11 & -0.77 & 0.39 & -0.61 & 0.24 \\
\hline $\mathbf{E} 4$ & $\begin{array}{l}\mathrm{RDF}+\mathrm{SSP}+0.5 \% \\
\mathrm{FeSO}\end{array}$ & -3.17 & 0.24 & -0.44 & 0.81 & -1.55 & -0.74 \\
\hline $\mathbf{E 5}$ & $\mathrm{RDF}+\mathrm{SSP}+\mathrm{ZnSO}_{4}$ & -2.37 & -0.28 & -3.81 & -2.01 & 4.13 & -0.75 \\
\hline $\mathbf{E 6}$ & $\begin{array}{l}\text { RDF }+\mathrm{SSP}_{+} \mathrm{ZnSO}_{4}+ \\
\text { 0.5\% }\end{array} \mathrm{FeSO}_{4}$ & -5.81 & -0.29 & -3.36 & -0.44 & -0.26 & 0.72 \\
\hline
\end{tabular}

*PH: Plant Height (cm), NBP: number of braches/plant, NPP: number of pods/plant, SYP: seed yield, Fe; iron content in seed, Zn: zinc content in seed

Appendix I Limits for different macro and micronutrients in soil.

\begin{tabular}{|c|c|c|c|}
\hline Macro/Micronutrient & Low & Medium & High \\
\hline N & $<250 \mathrm{~kg} / \mathrm{ha}$ & $250-500$ & $>\mathbf{5 0 0}$ \\
\hline $\mathbf{P}$ & $<10$ & $10-20$ & $>\mathbf{2 0}$ \\
\hline K & $<125$ & $125-300$ & $>\mathbf{3 0 0}$ \\
\hline S & $<10$ & $10-20$ & $>\mathbf{2 0}$ \\
\hline $\mathrm{Zn}$ & $0.6 \mathrm{ppm}$ & - & - \\
\hline $\mathrm{Cu}$ & $0.2 \mathrm{ppm}$ & - & - \\
\hline Fe & $4.5 \mathrm{ppm}$ & - & - \\
\hline Mn & $2.5 \mathrm{ppm}$ & - & - \\
\hline
\end{tabular}

A high environmental index shows the presence of negative GxE interaction and vice versa. Therefore, considering plant height, the environmental index Ij was highest in E1 and lowest in E6 meaning that E6 was the most favorable environment for plant height followed by E4, E5, E3 and E2. While the most unfavorable environment for this trait is E1. This might be because of the fact that in all other environments the soil was nutrient rich. For number of branches per plant, E6 and E5 are the most favorable environments, while the most unfavorable was E4.

For iron content, conditions in environment $\mathrm{E} 5$, the environment supplemented with only $\mathrm{ZnSO}_{4}$, were not good. In E5 the $\mathrm{Zn}$ uptake is good but this condition was not different from the $\mathrm{E} 4$ results. On the basis of Ij values, the E5 and E6 environments are favorable for most of the traits but not for iron and zinc content.

The genotypes studied in this chapter were selected from the first experiment based on per se performance, chemical analysis and diversity. Thirty genotypes were selected belonging to four separate clusters (Singh $e t$ al., 2017). Analysis of variance of quantitative traits showed highly significant differences among the genotypes among all environments. This indicated that the chosen genotypes had sufficient variability. The pooled analysis of variance showed that mean sums of squares (MSS) due to genotypes were highly significant for all the traits indicating 
enough variation. The MSS due to environmental conditions were also significant for almost all the traits indicating the validity of conducting an experiment as we did in artificial environments. The interactions were significant for almost all traits indicating considerable interaction between genotypes and environments for the expression of traits. The MSS due to environment + (genotype $\mathrm{x}$ environment) and environment (linear) was significant for all the traits indicating that environmental effects are additive. The linear component of $\mathrm{GxE}$ interaction was also significant for all the traits under study indicating a significant role of the linear response of the genotypes to environmental changes. Singh and Kumar (1994) and Popalghat et al., (1999) also reported differential ranking in their studies in chickpea. The pooled deviation was also found significant for all the traits indicating that the non-linear component of $\mathrm{GxE}$ interaction was predominant. Similarly, joint regression analysis reveals that MSS due to genotype was significant and thus supports that there is presence of significant variation among the genotypes for all traits under study. Both heterogeneity between regression $(\mathrm{GxE}$ interaction linear) and remainder (non-linear) was found significant for all the traits when tested against the pooled error. It indicates that prediction will depend upon the relative magnitude of these two measures. Further, the prediction will be more reliable when only heterogeneity between regressions is significant against the remainder (Samuel et al., 1970). Therefore, in the present study a prediction for plant height, iron and zinc content in seeds of mungbean will be reliable.

Soil analyses during the course of experiment showed some expected and unexpected results. The uptake of copper can be explained by the fact that manganese helps in uptake of copper while after harvest the zinc concentration in the soil was found to be higher as before sowing which may be thought of that excess amount of iron results in decrease in zinc uptake (RanadeMalvi, 2011) along with $\mathrm{Cu}$ presence which also reduces the availability of $\mathrm{Zn}$. Sulphur concentration in soil after harvest had a thirty times higher concentration in comparison to the initial stage analysis which was thought to be caused by super sulphate, which was added in the soil during the course of experiment. An environmental index reveals the favorability/adaptability of an environment at a particular location.

Breese (1969) pointed out that the estimates of the environmental index can provide the basis for the identifying the favorable environments for the expression of maximum potential of the genotype. As in the present study two major aspects were in consideration i.e. micronutrient (Fe and $\mathrm{Zn}$ ) and yield and its attributes. Therefore, on basis of the results of yield and its related traits, environment $1(\mathrm{E} 1)$ was found to be the most unfavorable. This may be related to the fact that this environment is not provided with single super phosphate which promotes the absorption of minerals from the soil. The second most unfavorable environment was E2 for all the traits except for iron content in seed. SSP was also not added in this environment which may be the reason for poor yield and its attributes. Adding SSP was found to be very important for pulses. Zinc uptake become lower after foliar spray of iron. For iron uptake E5 and E6 were unfavorable probably because of the added excess amount of $\mathrm{ZnSO}_{4}$ which hinders the iron uptake (Ranade-Malvi, 2011).

For yield E6 and E5, where both SSP and micronutrients were added, were found to be the most optimal. For iron content the most favorable environment was E4, which was expected as this environment SSP was added along with foliar spray of $\mathrm{FeSO}_{4}$ and no excess of $\mathrm{ZnSO}_{4}$. For zinc content E5 was the most favorable. Environment 6 is good for yield micronutrient uptake is lower showing that excess of micronutrients hinder their uptake (Ranade-Malvi, 2011). In our study and in other studies it was noticed that there was a variable pattern of response for the different traits in different environments (Popalghat et al., 1999). 
GxE limits the progress of crop improvement beyond the breeder's station. Nutritional quality of food legumes are subjected to variation caused by different environmental conditions. Dixon et al., (1991) define GxE interaction as the change in a cultivars relative performance over environments, resulting from differential response of the cultivar, to various edaphic, climatic and biotic factors. In the present study differential genotypic responses across the different created environments showed that the cultivars differ in response across different environments and thus this can complicate the evaluation and selection of cultivars for any specific purpose or trait like in the present study. This study shows the importance of studying the $\mathrm{GxE}$ interaction in mungbean improvement programs.

\section{References}

Breese, E.L., 1969. The measurement of significance of genotype $\mathrm{x}$ environmental interaction in grasses. Heredity 24, 26-44.

Dixon, A.G.O., R. Asiedu and Hahn, S.K. 1991. Genotypic stability and adaptability: Analytical methods and implications for cassava breeding for low input Agriculture. Proceedings of the 9th Sympossium of the International Society for Tropical Root Crops, October 20-26, 1991, Accra, Ghana, Pp: 130-137.

Jitendra, K., K.C. Arbind, K.S. Ramesh and Aditya P. 2011. Towards marker-assisted selection in pulses: a review. Plant $\mathrm{Br}$. 130, 297-313.

Mehla, I.S., R.S. Waldia and Dahiya, S.S. 2000. Phenotypic stability for some cooking quality attributes among kabuli chickpea
(Cicer arietinum L.) genotypes. J. of Genet. and Br. 54, 293-297.

Popalghat, G.R., J.V. Patil, R.B. Deshmukh and Mhase, L.B. 1999. Stability for yield and yield components in chickpea (Cicer arietinum L.). Legume Res. 22, 254-258.

Ranade, U.M. 2011. Interaction of micronutrients with major nutrients with special reference to potassium. Karnataka J. of Agric. Sci., 24(1):106-109.

Samuel, C.J.A., J. Hill, E.J. Breese and Davis, A. 1970. Assessing and predicting environment response in Lolium preme. Journal of Agriculture Science 75, 1-19.

Singh, O., and Kumar, S. 1994. Phenotypic stability of yield and related characters in desi gram (Cicer arietinum L.). Indian Journal Agric. Sci. 64,815-820.

Singh, R., A.W. Heusden, R. Kumar and Visser, R.G.F. 2016. Genetic variation and correlation studies between micronutrient (Fe \& $\mathrm{Zn}$ ), protein content and other quantitative traits in mungbean ( $V$. radiata L.)". Legume Res. (published online)

Singh, R., A.W. Heusden, R. Kumar, R.G.F. Visser and Yadav, R.C. 2013. Genetic Diversity of Mungbean (Vigna radiata L.) in Iron and Zinc Content as Impacted by Farmers' Varietal Selection in Northern India. Ecol Food Nutr. 52(2): 148-162.

Tiwari, S., V.K. Dwivedi and Tiwari, S. 2000. Stability studies in chickpea. Annals of Agric. Res. 21(1): 114 - 118.

Wu, R.L. and O'Malley, D.M. 1998. Nonlinear genotypic response to macro- and microenvironments. Theor. Appl. Genet. 96, 669-675.

\section{How to cite this article:}

Renu Singh, Adriaan W. Van Heusden, Suman Bala and Richard G.F. Visser. 2018. Differential Response of Mungbean (Vigna radiata L.) Varieties to Changes in Environmental Conditions. Int.J.Curr.Microbiol.App.Sci. 7(03): 2343-2350. doi: https://doi.org/10.20546/ijcmas.2018.703.275 